\title{
Effects of Selective Herbicide, Atrazine on the Rhizobium Population and Nodulation of Groundnut (Arachis hypogeae)
}

\author{
Johnson Oche Akor ${ }^{1 *}$, Dr. Monday Ubogu ${ }^{2}$ \\ ${ }^{1}$ Microbiology Department, University of Benin, Edo State, Nigeria \\ ${ }^{2}$ Microbiology Department, Federal University of Agriculture, Benue state \\ * Corresponding author E-mail address: ocheakor@gmail.com. Tel: +2347039020605
}

\begin{abstract}
Atrazine is a selective herbicide used to control weeds in farm operations. The effect of different concentrations of atrazine on Rhizobium population and nodulation in groundnut (Arachis hypogeae) was investigated using Yeast Extract Mannitol Agar (YEMA). The test crop was planted for 90 days after the soil was treated with the various concentration of atrazine. The following parameters; Rhizobium count, nodule count, plant height and germination percentage were observed. The total Rhizobium count obtained at $0 \%$ atrazine treatment has $3.0 \times 10^{8}, 0.1 \%$ has $2.9 \times 10^{8}, 0.5 \%$ has $2.5 \times 10^{8}, 1 \%$ has $2.0 \times 10^{8}$, and $3 \%$ has $1.4 \times 10^{8}$ all in cfu/ml while the number of root nodules formed was also counted after uproot which was; $0 \%$ atrazine treated has 50 nodules, $0.1 \%$ has 50 nodules, $0.5 \%$ has 30 nodules, $1 \%$ has 23 nodules and 3\% has 19 nodules. The study revealed that the higher the atrazine concentration the lower the population of Rhizobium, the numbers of root nodules increased with decrease in atrazine concentration and Plant height, root length and germination percentage was also affected adversely by increased in atrazine concentrations.
\end{abstract}

Keywords: Herbicide, atrazine, groundnut, Rhizobium, nodules. 


\section{Introduction}

Atrazine is an herbicide of the triazine class; selective herbicide for control of most annual broadleaf and grassy weeds in corn, sugar cane, sorghum, macadamia orchards, groundnut, rangeland, pineapple, and turf grass sod. It is one of the most widely used herbicides in the US and in Australian agriculture Rachel Aviv (2014). Herbicides, also commonly known as weed-killers, are pesticides used to kill unwanted plants. Selective herbicides kill specific targets, while leaving the desired crop relatively unharmed. Some of these act by interfering with the growth of the weed and are often synthetic mimics of natural plant hormones. Herbicides are broadly classified into selective and non-selective, where atrazine is among the selective. Herbicides used to clear waste ground, industrial sites, railways and railway embankments are not selective and kill all plant material with which they come into contact. Smaller quantities are used in forestry, pasture systems, and management of areas set aside as wildlife habitat. Herbicides are widely used in agriculture and landscape turf management. In the US, they account for about $70 \%$ of all agricultural pesticide use (Kellogg et al., 2000).

It is also a non-selective herbicide on non-cropped industrial lands and on fallow. It is available as dry flourable liquid, water dispensable granular and wet able powder formulation. Atrazine is an herbicide that is used to stop pre and post-emergence broadleaf and grassy weeds in crops such as sorghum, maize, sugarcane, lupins, pine and eucalypt plantations, and triazine tolerant (TT) canola Chemical review, (2014).

Rhizobium is a genus of Gram-negative soil bacteria that fix nitrogen. Rhizobium forms an endosymbiotic nitrogen fixing association with roots of legumes. The bacteria colonize plant cells within root nodules; here the bacteria convert atmospheric nitrogen to ammonia and then provide organic nitrogenous compounds such as glutamine or urea to the plant. The plant provides the bacteria with organic compounds made by photosynthesis (Sawada et al., 2003).

Rhizobia are symbiotic diazotrophs (prokaryotic organisms that carry out dinitrogen fixation) that form a symbiotic association with legumes. This association is symbiotic in that both the plant and rhizobia benefit. The plant supplies the rhizobia with energy in the form of amino acids and the rhizobia fix nitrogen from the atmosphere for plant uptake. The reduction of atmospheric dinitrogen into ammonia is the second most important biological process on earth after photosynthesis (Sylvia et al., 2005)

Nodulation is an infection process that lead to the swollen of roots of plant especially legumes when bacterial like Rhizobium or other related species gain entrance into the root hairs forming nodules. In general, two main types of nodules exist: determinate and indeterminate. Determinate nodules are spherical and develop from a non-persistent hemispherical meristem while indeterminate nodules are elongated and cylindrical and develop by distal growth from a persistent apical meristem (Fransen et al., 1992).

Groundnut is a Legume; legumes are plants that produce nitrogen fixing root or stem nodules which forms symbiotic association with Rhizobium. They include beans, peas, clovers and soybean (Harrison, 2003). Groundnut possesses a high symbiotic nitrogen fixing capacity. The amount of nitrogen accumulated by groundnut is high compared to other tropical legumes (Van Rossum, D. 1994). Groundnuts are grown in large-scale, mechanised agricultural systems and in small-scale or subsistence systems. Pod yield in subsistence farming systems is much lower, at $780 \mathrm{~kg} \mathrm{ha}^{-1}$ on average, than in large-scale, mechanised 
systems, with $2900 \mathrm{~kg} \mathrm{ha}^{-1}$ on average. McDonald, D. (1985). Approximately $90 \%$ of the world groundnut crop is produced in developing countries.

\section{Materials and Methods}

\section{Sterilization of Materials}

All glassware was thoroughly washed with detergent solution, rinsed with a lot of distilled water and subsequently allowed to drain, after which they were sterilized in the oven at $170^{\circ} \mathrm{C}$ for 2 hours. All culture media were sterilized by autoclaving at $121^{\circ} \mathrm{C}$ for 15 minutes. The inoculating loop was sterilized by flaming to red hot on a Bunsen flame then dipped into absolute alcohol to cool before each use.

\section{Soil Analysis}

The soil used was an acidic sandy loamy soil classified as ferralitic sandy loam (D'Hoore, 1964) collected from college of science environment of University of Agriculture, Makurdi, Nigeria. The soil had no previous exposure to petroleum hydrocarbons. The physicochemical characterization of the soil samples were carried out using standard methods. The initial soil sampling was carried out for routine analysis. The soil samples were collected at a depth of $0-15 \mathrm{~cm}$, air dried and sieved through a $2 \mathrm{~mm}$ sieve. The particles size distribution was determine by the pipette method of (Gee and Bauder, 1986). Soil $\mathrm{pH}$ was done using 1:2 soil/water volume ratios on a digital $\mathrm{pH}$ meter (model EQ-610.). Total nitrogen was estimated by macro-Kjeldhal procedure (Jacson, 1962).

\section{Soil Treatment}

The soil collected from college of sciences in the University of Agriculture Makurdi, Benue state Nigeria was not previously exposed to Atrazine or any other form of selective chemical. Each experimental unit has $4 \mathrm{~kg}$ of the soil weighed into pots. The atrazine was applied evenly using a fine hose and properly worked into the soil in each of the treatments $(0 \%, 0.1 \%$, $0.5 \%, 1 \%$, and $3 \%$ ) and replicated three times. The pots were then labeled and exposed to ambient conditions for ten days before planting the test crop. Pots containing soil with no supplements $(0 \%)$ served as control.

\section{Cultivation of Test Crop}

Groundnut (Arachis hypogeal) belonging of the legume family fabaceae was bought, steeped, and viable seeds selected were planted in the pots containing four (4) seeds per pot to create space for growth and watered but not flooded every day.

\section{Enumeration of Nodulation}

The test plant was uprooted after three months and the root nodules was counted per plant on each pot, alongside the plant height, root length and number of pod formed.

\section{Preparation of Media}

the media used is YEMA (Yeast Extract Mannitol Salt Agar) which is a complex medium prepared by measuring the following into $400 \mathrm{ml}$ of distilled water in a conical flask (Mannitol salt agar 4gm, Yeast extract powder $0.4 \mathrm{gm}$, Agar powder $8 \mathrm{~g}, \mathrm{MgSO}_{4} 0.08 \mathrm{~g}$, $\mathrm{K}_{2} \mathrm{PO}_{4} 0.2 \mathrm{~g}, \mathrm{NaCl} 0.04 \mathrm{~g}$ and Congo Red $0.01 \mathrm{~g}$ ). It was then homogenized by heating until the 
whole mixture dissolved in the water. The medium was then sterilized in the autoclave at $121^{\circ} \mathrm{C}$ for 15 minutes. It was brought out of the autoclave and allowed to cool to $45^{\circ} \mathrm{C}$ before it was poured aseptically into sterile Petri-dishes.

\section{Isolation of Rhizobium from Nodules}

Plants were uprooted carefully and nodules were collected from the roots, washed with sterile water followed by surface treatment with $95 \%$ alcohol and again with sterile water.

The washed nodules were surface sterilized with $0.1 \%$ mercuric chloride for $2-3$ minutes and again washed for at least 10 times with sterile water as to remove the traces of mercuric chloride. The nodules were transferred in culture tube half filled with sterile water and crushed with a sterile glass rod to obtain a milky bacterial suspension. A fivefold serial dilution $\left(10^{-1}, 10^{-2}, 10^{-3}, 10^{-4}, 10^{-5}\right)$ from which $0.1 \mathrm{ml}$ of dilution $10^{-3}$ and $10^{-5}$ was plated out in replicate on Yeast extract mannitol (YEM) agar media by pour plate method and incubated for 4 (four) days at $28^{\circ} \mathrm{C}$. After which colony count is taken.

\section{Characterization and Identification of Rhizobium}

\section{Colonial Morphology}

All isolates showed the same colony characteristics, after 48 hours of incubation. The colonies were milky white, translucent, circular in shape, shiny, raised and 2-4 $\mathrm{mm}$ in diameter. Log phase culture in $0.1 \mathrm{ml}$ quantity of the isolated root nodulating bacteria (RNB) strain was spread over YEM agar plates Strains were also streaked on YEM agar. The inoculated plates were incubated at $28^{\circ} \mathrm{C}$ for 48 hours and observed for colony shape, size, colour and texture. Fast growing rhizobia generally produce white, semi translucent, circular, mucilaginous colonies while slow growing strains produce white, opaque, circular, granular colonies, which do not exceed $1 \mathrm{~mm}$ in diameter after prolonged incubation.

\section{Cellular Characteristic}

This was studied by using Gram staining techniques and then viewed under the microscope for cell identification.

\section{Smear Preparation}

This was done as described by Fawole and Oso (2004). A drop of sterile water was placed in the middle of a clean grease-free slide. A sterile wire loop was then used to touch the bacteria colony which was then emulsified in the drop of sterile water already on the slide. It was then spread into a thin smear after which it was the allowed to air-dry. The reverse-side of the slide was then passed quickly over the flame three (3) times to fix the bacteria. The slide was then allowed to cool properly before staining commenced.

\section{Gram Staining}

This was done to group the bacteria isolates into Gram-positive and Gram-negative bacteria. It was also used to know the shape and arrangement of the cells of bacteria. Already prepared smears were first flooded with Crystal violet stain for 30-60 seconds after which they were rinsed with clean water and drained. Lugol's iodine was added and left for 30-60 seconds after which they were rinsed with clean water and drained. The slides were then washed with 95\% alcohol for a few seconds until the slides appeared free of stain. They were then washed 
with water and drained after which safarin was used to flood the smears for 60 - 120 seconds. The slides were then rinsed with clean water, the opposite sides of the slides were cleaned with cotton wool and they were placed on the draining rack to dry. The drained slides were then examined with oil immersion under x10 objective lens of the microscope. Gram-positive bacteria gave blue to purple color while Gram-negative bacteria were pink to red in colour.

\section{Biochemical Tests}

These were tests done in order to identify bacteria based on their biochemical activities. The biochemical tests were done as follows:

\section{Catalase Test}

This was done to differentiate between bacteria that produce the enzyme catalase from the non-catalase producing bacteria. This enzyme breaks down Hydrogen peroxide into water and oxygen i.e.

$$
2 \mathrm{H}_{2} \mathrm{O}_{2} \longrightarrow 2 \mathrm{H}_{2} \mathrm{O}+\mathrm{O}_{2}
$$

This was done by putting a few drops of Hydrogen peroxide on a clean slide. A sterile wire loop was used to pick colonies of bacteria and it was placed in the Hydrogen peroxide. Presence of bubbles indicated a positive result.

\section{Coagulase Test}

The enzyme coagulase causes plasma to clot. This test was used to differentiate between coagulase-producing bacteria from the non-coagulase producing bacteria. Although, there are two (2) methods (slide test and tube test), the slide test was used in this project work. Plasma $(1 \mathrm{ml})$ was poured on a clean slide with a syringe. Colonies were then picked with a sterile inoculating loop and dropped on the slide. It was then mixed with the loop while been observed for clumping. Presence of clumping indicated a positive result.

\section{Oxidase Test}

This test was used to identify bacteria that produce cytochrome oxidase. Colonies of bacteria were picked with sterile inoculating and smear was made on a filter paper. It was moistened with oxidase reagent and it was observed for colour change developing within 15 seconds indicated a positive result.

\section{Citrate Utilization Test}

This test was used to differentiate a bacterium that uses citrate as their only carbon source breaking it down into organic acid and carbon (IV) oxide. Bacterial colonies were streaked on the surface of the solidified slants. It was then incubated at $37^{\circ} \mathrm{C}$ for 48 hours. A bright blue colouration indicated a positive result.

\section{Urease Production Test}

This test was done to differentiate between groups of bacteria, some of which produce urease enzyme, an enzyme that break down into ammonia and carbon (IV) oxide. Urea agar slants were prepared and they were inoculated with bacteria. They were incubated at $37^{\circ} \mathrm{C}$ for 24 hours. A pink colouration indicated a positive. 


\section{Indole Production Test}

This test was used to identify bacteria that can hydrolyze the amino acid, tryptophan, with the release of indole. Indole is detected with Kovac's reagent. It was done by preparing peptone water and then $3 \mathrm{ml}$ was poured into each Mc Cartney bottles used. Colonies of bacteria were then picked with sterile inoculating loop and then introduced into the peptone water. It was then mixed properly. They were then incubated at $37^{\circ} \mathrm{C}$ for 24 hours. After incubation, $2 \mathrm{ml}$ of Kovac's reagent was added and shaken properly. It was allowed to stand for 20 minutes. A red colour at the top indicated a positive result.

\section{Motility Test}

Hanging-drop technique as described by Fawole and Oso (2004) was used. Slides were examined for motility under the microscope. The diaphragm was closed to reduce the light intensity for clear vision.

\section{Results}

Table 1: Physical and chemical characteristics of the soil before applying various concentration of atrazine

\begin{tabular}{lc}
\hline Characteristics & values \\
\hline Soil texture & \\
Sand(\%) & 76.0 \\
Clay(\%) & 16.0 \\
Silt $(\%)$ & 8.0 \\
pH & 6.9 \\
organic carbon (\%) & 1.1 \\
organic matter $(\%)$ & 1.9 \\
nitrogen(\%) & 0.09 \\
phosphorus(mg/kg) & 0.4 \\
water holding capacity (\%) & \multicolumn{2}{c}{71.4} \\
\end{tabular}

The physio-chemical properties of the soil before applying atrazine treatment is presented in table 1. The soil, an acidic sandy clayey soil with a little quantity of silt, no hydrocarbon content, had originally considerable amount of nitrogen $(0.09 \%)$, available phosphorus $(0.4 \mathrm{mg} / \mathrm{kg})$, organic matter of $(1.9 \%)$ and organic carbon $(1.1 \%)$ with a neural $(\mathrm{pH})$. 
Table 2: Cultural morphology and biochemical characteristics of Rhizobium isolate.

Cultural morphology and Result/characteristics

Biochemistry test performed

Gram stain reaction

Shape of organism

Odour

Elevation

Outline

Consistency

Appearance under light

Size

Colour

Spore formation

Motility

Catalase test

Indole test

Urease test

Citrate test

$\mathrm{NaCl}$ tolerance $(30 \%)$

Mannitol

\author{
Negative \\ Rod \\ Masky \\ Raised and curved \\ Circular \\ Viscous/mucoid
}

Translucent with glassy

2-4 $\mathrm{cm}$ in diameter

Whitish and creamy

Negative

Positive

Positive

Negative

Negative

Negative

Negative

Positive

The cultural morphology and biochemical test of Rhizobium isolate is shown by table 2 . The organism Rhizobium is Gram negative, rod shaped, translucent in appearance, whitish and creamy in colour, motility positive, catalase positive, indole negative, citrate negative, urease negative, tolerate $\mathrm{NaCl}$ at $30 \%$ and mannitol positive.

Table 3: Effect of different concentration of Atrazine on the growth height of groundnut (Arachis hypogeal)

\begin{tabular}{lc}
\hline Concentration of atrazine & height $(\mathrm{cm})$ \\
$\% \mathrm{~V} / \mathrm{W}$ & \\
\hline $0 \%$ & 18 \\
$0.1 \%$ & 15 \\
$0.5 \%$ & 12 \\
$1 \%$ & 10 \\
$3 \%$ & 8
\end{tabular}

Values $=$ mean of triplicate pots

Table 3 shows the effect of the various atrazine concentration on the plant height which is observed to decrease with increase in the concentration of atrazine. 
Table 4: Effect of different concentration of Atrazine on the root length of groundnut (Arachis hypogeal)

Concentration of atrazine $\quad$ root length $(\mathrm{cm})$

$\% \mathrm{v} / \mathrm{w}$

\section{Values $=$ mean of triplicate pots}

The root length of groundnut is shown by table 4, which is also observed like the effect on the plant height to decrease in length when the concentration of atrazine increases (from $0 \%$, $0.1 \%, 0.5 \%, 1 \%$, and $3 \%$ ).

Table 5: Effect of different concentration of Atrazine on the germination time of groundnut (Arachis hypogeal)

\begin{tabular}{ll}
\hline $\begin{array}{l}\text { Concentration of atrazine } \\
\% \mathrm{v} / \mathrm{w}\end{array}$ & germination time (days) \\
\hline $0 \%$ & 4 \\
$0.1 \%$ & 4 \\
$0.5 \%$ & 5 \\
$1 \%$ & 8 \\
$3 \%$ & 10
\end{tabular}

\section{Values $=$ mean of triplicate pots}

Table 5, shows the effects of the various concentration level on the germination time of groundnut, which shows clearly that the higher the concentration the longer time it takes for the seed to germinate. 
Table 6: Effect of different concentration of Atrazine on germination percent of groundnut (Arachis hypogeal)

Concentration of atrazine

$\% \mathrm{v} / \mathrm{w}$

$0 \%$

$0.1 \%$

$0.5 \%$

$1 \%$

$3 \%$ germination percent $(\%)$

100

100

75

58.3

\section{Values $=$ mean of triplicate pots}

The number of seeds that germinated in each replicate of the various treatment level seemed to decrease with increase in atrazine concentration as shown in table 6.

Table 7: Effect of different concentration of Atrazine on the time of withering of groundnut (Arachis hypogeal)

\begin{tabular}{lc}
\hline $\begin{array}{l}\text { Concentration of atrazine } \\
\% \text { v/w }\end{array}$ & withering time (days) \\
\hline $0 \%$ & nil \\
$0.1 \%$ & nil \\
$0.5 \%$ & nil \\
$1 \%$ & 69 \\
$3 \%$ & 60
\end{tabular}

Values $=$ mean of triplicate pots

From table 7, it was observed that some treatment such as the $1 \%$ and $3 \%$ of atrazine concentration after delayed germination shows signs of withering after $60^{\text {th }}$ day for the $3 \%$ and $69^{\text {th }}$ day for the $1 \%$. 
Table 8: Effect of different concentration of Atrazine on nodulation count of groundnut (Arachis hypogeal)

Concentration of atrazine nodule count per plant

$\% \mathrm{v} / \mathrm{w}$

$0 \%$

$0.1 \%$

$0.5 \%$

$1 \%$

$3 \%$

\section{0}

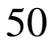

30

23

19

\section{Values $=$ mean of triplicate pots}

The safely uprooted plant has it nodules counted (0ne per treatment) and it is observed to decrease in number with increase in concentration as shown in table 8 .

Table 9: Effect of different concentration of Atrazine on the population of Rhizobium isolated from the root nodules of groundnut (Arachis hypogeal)

\begin{tabular}{ll}
\hline $\begin{array}{l}\text { Concentration of atrazine } \\
\% \mathrm{v} / \mathrm{w}\end{array}$ & Rhizobium count $(\mathrm{cfu} / \mathrm{ml})$ \\
\hline $0 \%$ & $3.0 \times 10^{8}$ \\
$0.1 \%$ & $2.9 \times 10^{8}$ \\
$0.5 \%$ & $2.5 \times 10^{8}$ \\
$1 \%$ & $2.0 \times 10^{8}$ \\
$3 \%$ & $1.4 \times 10^{8}$
\end{tabular}

\section{Values $=$ mean of triplicate pots}

Table 9 accounts for the number of Rhizobium seen and counted in each of the average planting which shows a trend of reduction in number per percentage increase in concentration. Where $0 \%$ has $3.0 \times 10^{8}, 0.1 \%$ has $2.9 \times 10^{8}, 0.5 \%$ has $2.5 \times 10^{8}, 1 \%$ has $2.0 \times$ $10^{8}$, and $3 \%$ has $1.4 \times 10^{8}$ all in $\mathrm{cfu} / \mathrm{m}$

\section{Discussion}

in the study, the effect of selective herbicide, atrazine in the Rhizobium population and nodulation in groundnut (Arachis hypogeal), revealed several adverse effects both on the legumes' capacity to mutually enhance the nitrogen fixation, the microbial community of the rhizosphere and the physic chemical properties of the soil. The presence of the atrazine in the soil from the study tend to reduce the quantity of nitrogen in the soil, which effect on the 
yellowing and withering of the groundnut plant, this is in accordance with (Walley et al., 2006) that pesticides and herbicides reduce plant growth and promotes shoot yellowing. A research carried out by Black, (2002) that bacteria affects the physical characteristics of soil and other soil organisms, this proved why the quantity of the soil minerals like nitrogen increases in the soil after planting a legume because of the fixation of nitrogen by the nitrogen fixing bacteria.

The plant in question which is groundnut from the field observation and the result tabulated shows that the chemical concentration of atrazine has toxic effect on the plant growth, plant height, root length of the plant, the number of pods forms and the leaf development. It is also observed that the higher the atrazine concentration the more toxic effects it has on the plant general growth and development. This is because the control experiment which has zero percent of the chemical seemed to show good and normal growth and development than the others with atrazine application. This must be that abnormal concentration of the chemical is toxic to the plant. This is in agreement with the work of (Khan et al., 2004) that various toxicity of herbicides on legume plants has been reported. Also Adenikinju (2003) propagated that since atrazine is a selective pre-emergence herbicide it has no effect, but Ackerman Frank (2007) said that atrazine has no or reduced adverse effect on corn which agrees with the work of (Khan et al., 2004); this is because corn is not a legume.

Nodulation which is carried out by Rhizobium and other related species in legume plant show adverse effects when atrazine was applied at various concentrations. It was observed experimentally that the numbers of root nodules formed decrease with increase in the chemical concentration on the experimented samples as shown in table 8. These findings agreed with the finding and publication of Fox J.E. (2007) that the herbicide atrazine interferes with legume-Rhizobium chemical signaling which reduces nitrogen fixation and does reduces crop yield. It is also in agreement with the work of H Jansen, Van Rensburg and B.W.Strijdom (1984) that nodulation and nitrogen fixation are frequently adversely affected by herbicides on legumes. From this study and the present experiment, it is right to deduct that the number of nodule count is affected adversely by increase in atrazine application especially above normal.

Rhizobium population in the root nodules is from the experiment conducted affected by the atrazine concentration. It follows a trend that the higher the concentration the lower the number of Rhizobium. This is shown in table 9. From the work of Singh and Wright (2002), and (Agmail et al., 2004) it was postulated that some chemicals are incompatible with Rhizobium. (Araujo et al., 2003) went as far to observe that atrazine alters soil microbial population and metabolites by enhancing mycobacteria and fungi while decreasing bacteria and photosynthetic microorganisms. It is still (Araujo et al., 2003) that also said that atrazine kills off plant-like microorganisms. Although (Liphadzi et al., 2005) found no side effect. However, judging from the fact that soil microbiota is in constant interaction, it is right to predict that the effect on some Rhizobium symbionts also is a direct effect on Rhizobium populace. WSSA herbicide handbook (2001) proposed that atrazine is harmful to susceptible and metabolizes the tolerant. A work by (Appleby et al 2001) proved that atrazine causes oxidative damage in the presence of high light intensity to both soil microbes and plants. 


\section{Conclusion}

This study revealed that the chemical concentration of atrazine has toxic effect on the Rhizobium population, plant growth, plant height, root length of the plant, the number of pods forms and the leaf development. It is also observed that the higher the atrazine concentration the more toxic effects it has on the plant general growth and development. This is because the control experiment which has zero percent of the chemical seemed to show good and normal growth and development than the others with atrazine application. This research contribute to knowledge that aside the many adverse effects of the chemical on the soil and water bodies it has higher effect on agriculture when not used in the right concentration, therefore overusage should be minimized to protect and maintain the organic soil.

\section{ACKNOWLEDGEMENT}

I would want to thank my co-author, Dr Monday Ubogu and the Federal University of Agriculture Makurdi for the enabling environment to conduct this research. 


\section{REFERENCE}

1. Aamil M., Zaidi A., Khan M.S., 2004. Effect of herbicides on growth, nodulation and yield of chickpea (Cicer arietinum L.). Ann. Pl. Protec. Sci. 12, 186-191.

2. Ackerman, Frank, 2007. "The economics of atrazine". International Journal of Occupational and Environmental Health 13 (4): 437-445

3. Adenikinju, C. Screpant, 2003. Short-time effects of pure and formulated herbicides on soil microbial activity and biomass. $P 90$.

4. Appleby, Arnold P., Müller, Franz, Carpy, Serge, 2001. "Weed Control". Ullmann's Encyclopedia of Industrial Chemistry. ISBN 3-527-30673-0

5. Araujo A.S.F., Moniteiro R.T.R., Abarkeli R.B., 2003. Effect of glyphosate on the Microbial activity of two brazillian soils. Chemosphere, 52: 799-804.

6. Black, 2002. Toxicity of Atrazine on Invertebrate.

7. Chemical Review: Atrazine". Australian Pesticides and Veterinary Medicines Authority. Retrieved 2014-02-05.

8. Fawole, M.O. and Oso, B.A., 2004. Laboratory Manual of Microbiology. Spectrum Books Limited, Ibadan, Nigeria.

9. Fox, J.E, Gulledge, J., Engelhaupt, E., Burrow, M.E., and McLachlan, J.A., 2007. Pesticides reduce symbiotic efficiency of nitrogen-fixing rhizobia and host plants. Proceedings of the National Academy of Sciences of the USA.

10. Fransen, H.J., Vijn, I., Yang, W.C. and Bisseling, T., 1992 Developmental aspects of the rhizobium-legume symbiosis. Plant Mol. Biol. 19, 89-107.

11. Gee, G.W., Bauder, 1986. Particle size analysis. In: Method of soil Analysis part 1(ed. Aklote). American society of Agronomy Madison WL, VSA. pp.387-407

12. H. Jansen van Rensburg \& B. W. Strijdom, 1984 Effect of herbicides on survival of rhizobia and nodulation of peas, groundnuts and lucerne, South African Journal of Plant and Soil, 1:4, 135-138,

13. Harrison, J.A., 2003. The Nitrogen cycle of Microbes and Man. Vision

14. Hoore, J.D., 1964. Dongne, Hertley and Watson soil classification scheme In: Soil map of Africa explanatory monograph. p. 202

15. Jacson, W.L., 1962. Soil Chemistry Analysis. Prentice - Hall Inc. Englewood. New Jersey. pp. 205-226.

16. Kellogg, R.L., Nehring, R., Grube, A., Goss, D.W., and Plotkin, S., 2000. Environmental indicators of pesticide leaching and run off from farm fields. 
17. Khan, M.S., Zaidi, A., Aamil, M., 2004. Influence of herbicides on chickpea Mesorhizobium symbiosis, Agronomie 24, 123-127.

18. Liphadzi, R., Willey, S.I., Parison, T.F., Brown, (2003). Soil quality-determination of dry bulk density. International Organization for Standardization. P.10.

19. McDonald, D., 1985. The ICRISAT groundnut program. In: Proceedings of the regional Groundnut Workshop for Southern Africa (McDonald, D., Ed.), Intern. Crops Res. Inst. for the Semi-Arid Tropics, Patancheru, India.

20. Sawada, H., Kuykendall, L.D., Young, J.M., 2003. Changing concepts in the systematics of bacterial nitrogen-fixing legume symbionts. J. Gen. Appl. Microbiol. 49 (3): 155-79.

21. Singh, G., Wright, D., 2002. In vitro studies on the effect of herbicides on the growth of rhizobia Let. Appl. Microbiol. 35, 12-16.

22. Sylvia, D.M., Fuhrmann, J.J., Hartel, P.G., and Zuberer, D.A., 2005. Principles and Applications of Soil Microbiology. 2nd Edition. 373 - 404

23. Van-Rossum, D., 1994. The groundnut-Bradyrhizobium symbiosis. Symbiotic, physiological and molecular characterisation. Ph.D. thesis, Vrije Universiteit, Amsterdam, The Netherlands.

24. Walley, F., Taylor, A., Lupwayi, N., 2006. Herbicide effects on pulse crop nodulation and nitrogen fixation. FarmTech Proceedings: 121-123.

25. WSSA Herbicide Handbook Committee, 2001. Herbicides handbook of the weed science society of America, $6^{\text {th }}$ Ed. W.S.S.A 